\title{
A Survey on English Learning Difficulties of Higher Vocational College Students and the Countermeasures
}

\author{
Jie HE \\ Fengxiang Normal School \\ Baoji Vocational Technology College \\ Baoji, Shaanxi 721400, China
}

\begin{abstract}
This article analyzes learning motivation, interest, attitude, confidence, methods, language anxiety, self-evaluation and evaluations to learning materials of higher vocational college students, which further finds reasons causing learning difficulty of higher vocational college students in learning English. That is, insufficient learning interest, passive learning attitude, easily influenced, less effort, weak English foundation, obsolete learning methods, high language anxiety and incorrect self-attribution. For those reasons, firstly, the learning interest should be aroused and intrinsic and integrative motivations should be developed. Secondly, Learning attitudes and confidence should be rectified and established in the language teaching. Thirdly, a good volitional quality of the students should be cultivated. Fourthly, a good learning environment must be created; meanwhile, self-teaching consciousness and abilities should be developed as well. Fifthly, outmoded teaching methods and techniques need to be abandoned and improved. Finally, the systematicness, practicality, stability and pertinence of the development of teaching materials need to be enhanced.
\end{abstract}

Keywords- Higher vocational college students; English learning; learning difficulties; learning motivation; selfevaluation; learning interest

\section{INTRODUCTION}

In recent years, with the arrival of global economic integration and information era as well as the rapid development of economy and social undertakings in China, all trades and professions in the society are urgently in need of all kinds of high-talented personnel, among which they include the task to foster high-quality professional and technical persons that have certain professional knowledge and skills for the frontline of production, construction, management, and services. As an important component of the higher education, the higher vocational education has been playing a crucial part in implementing strategies of rejuvenating China through science, technology and human resource development.

Satisfactorily, the higher vocational education has been developing tremendously and has received great attention to since 1990s. A large number of old higher vocational colleges have been consolidated and upgraded and they have cultivated many high-talented personnel. As a rising star of the higher education, the higher vocational education increasingly shows its huge development potential and promising prospect. According to "Fundamental Requirements for English Course in Vocational and Threeyear Colleges", the English teaching objective of HVCs is to make students master certain fundamental knowledge and skills, have ability of listening, speaking, reading, writing and translating/interpreting and enable to use dictionaries to read and translate some special collections. Meanwhile, students should be good at communicating with each other in oral and written forms and laying a solid foundation for further study in the future. In teaching, teachers should pay close attention to the learning interim and emphasize the importance of training English elementary knowledge and skills. Especially, the English practical competence of students should be enhanced and trained, and the guidance of practicality and sufficiency should be observed in the classroom teaching as well. As for the situation mentioned above, the study will focus on the following questions:

(1) Are there any differences among the vocational college students in the three HVCs investigated in learning difficulties? What learning difficulties do the higher vocational college students have in common? Which are the prime difficulties in learning English?

(2) What factors primarily cause the learning difficulties and passive participation of the higher vocational students in the classroom?

(3) Are there any gender, school and major differences among the higher vocational college students in learning difficulties?

(4) What possible countermeasures should be taken to effectively deal with the learning difficulties and passive participation of the higher vocational college students in the classroom?

\section{LITERATURE REVIEW}

\section{A. Researches on Learning Difficulties Abroad}

Researches on learning problems have recently focused on foreign language learning difficulties, which mainly refers to learners' specific troubles in learning a second language or foreign language (Ganschow \& Sparks, 1995; Ganschow, Sparks, \& Javorsky, 1998; Palladino, 2003). From the point of a family environment, factors causing learning difficulties and behavioral problems are those such as parental mental problems, parental education to a child, marital problems and child management practices. In the 
opinion of Sparks (2006), "there is no empirical evidence to support a distinct 'disability' for foreign language learning." He suggests that we should use foreign language learning problems, poor foreign language learners, or low-achieving foreign language learners to replace the word "disability" when describing learners who find foreign language learning to be difficult for them. From the angle of dealing with learning difficulties, Adams and Bee (1991) describe how to employ teaching strategies to renew learning confidence of college students with LD. They claim that learning disability is a generic term that refers to diverse disorders shown by severe difficulties in language learning such as application of listening, speaking, reading, writing or mathematical abilities. These disorders are inherent to individual learners and are assumed to be caused by central nervous system dysfunction.

According to Kavale and Mostert (2004), learners with LD frequently manifest a great deficiency of social skills and they use social skill interventions to treat those learners with LD. However, a research carried out by Simmons, Kameenui and Chard (1998) discusses teachers' beliefs about learning and their capabilities influencing learners' classroom performances at school. In that study, assumptions of 29 general instructors are examined through the design of a target lesson for learners with LD and results indicate that general instructors believe that learners are central and fundamental to learning, evaluate that lessons are quite inadequate for learners with LD and think that they have rich knowledge and skills to adjust limitations of commercial curricular lessons for learners with LD. In addition, Kaler and Kopp (1990) argue that there is a close relation between emotional and behavioral difficulties and language learning difficulties.

\section{B. Researches Related to Learning Difficulties in China}

In China, Chen (2001) claims that students fail to learn a foreign language because of a lack of learning motivation. He argues that Chinese college students of regarding English as a foreign language mainly display language foundation problems that are the potential reasons of $\mathrm{LD}$ and poor performances in academic achievements and it is these problems that may cause a shortage of learning motivation in turn (Chen 1997a, 1997b ). Fan and Rui (1998) assume that major foreign language learning difficulties of adult students are stemmed from the detachment between the foreign language learning and the development of cognition.

Additionally, Yao (2002) explores factors of spoken English LD among middle school students from two aspects of external and personal factors. The results show that a lack of speaking opportunity, heavy school work, low quality of English teachers, laziness in learning and excessive demands for speaking are chiefly included. Qin and Yin (2009) argue that low language aptitude, learning interest, self-regulation and confidence, high anxiety and incapable to make the best use of classroom learning opportunities give rise to LD. An investigation carried by Yuan (2006) concludes that reasons of English LD in HVCs are owing to weak learning basis and dull English teaching. Similar results concluded by Huang (2008) show that one of the major reasons of LD among higher vocational students is the weak learning basis as well.
But Zheng and Lou (2004) explain reasons of English LD from the point of view of psychology and they state that a lack of perseverance, insufficient learning motivation, passive avoidance in learning, higher anxiety, negative mentality and negative influences from the society (e.g. Internet) are main causes of it.

\section{RESEARCH DESIGN}

\section{A. Participants}

The participants came from three HVCs of Baoji city. All the participants are freshmen of the second term because they have already known something about teaching methods of the college English and their concrete LD or problems and are familiar with the college lives.

\section{B. Instruments}

To ensure a smooth implementation of the present research and the validity and reliability of the data collection in this survey, three instruments including a questionnaire concerning learning difficulties, an open-ended interview and multi-perspective classroom teaching observations were introduced and applied.

\section{RESEARCH FINDINGS}

\section{A. Major Learning Difficulties of Higher Vocational Students}

Most of them lack a long-term learning impetus and are apt to be influenced or interrupted by external factors. Moreover, quite a few students have low self-regulation and self-efficacy. It is the weak basis that gives rise to low ability in listening and speaking. What's more, they cannot express their own opinions or ideas clearly in English either. Most of them are poor in initiative, and do not have a good learning habit of preparing a lesson before a class, concentrating on a lesson during a class and reviewing a lesson after class.

\section{B. Main Reasons of Learning Difficulties}

Generally most of the higher vocational college students have a quite weak English basis. It is the unclear and unitary learning motivation that causes the lack of learning enthusiasm and initiative and to be easily distracted by external factors. At the same time, the family, school and society do not have appropriate expected value to them either and they do not have too much pressure to learn English. The lack of learning interest, persistence, endeavors and appropriate learning methods make the students put much less time and energy into learning English. Meanwhile, the school education deviates from the track of quality-oriented education. Frequent changes and inappropriate selection of learning materials and teachers are important interference factors to learn English as well.

\section{Measures of English Teaching for Higher Vocational Students}

1) Stimulating the Internal Impetus of students It is vital to develop the students' multiple learning motivation. Firstly, teachers make the students identify their 
learning purposes, strengthen their initiative in learning and change their attitudes of passive learning. Secondly, teachers should enhance the novelty, vitality, instructiveness and interactivity in teaching and stimulate students' interest to learn English. Thirdly, teachers should pay close attention to their teaching evaluations and feedbacks to the students. Fourthly, teachers and head teachers together manage to construct a good academic atmosphere for the students, encourage the students to compete with each other in learning and advocate cooperative or autonomous learning among the students.

It is necessary to help the students hold a correct learning attitude and build up self-confidence. English teachers should actively cooperate with head teachers to direct and instruct students to establish a positive attitude and strong self-confidence to English through class meetings, blackboard newspapers, seminars, colloquium and visits and so on. Firstly, teachers should seize each opportunity to properly praise or encourage students. Secondly, it is assumed that a psychological hint and reinforcement which can help students get over the hurt of failure must be taken to regain their self-confidence and stimulate their learning motivation.

Stimulating the students' interest to study is an important means to deal with learning difficulties. Firstly, creating positive expectancy and stimulating aspiration to knowledge should receive great attention. Secondly, it is necessary for teachers to promote innovative teaching and arouse students' enthusiasm to study. As a special learning community, in teaching teachers should think more about their instructional strategies and transform their teaching methods which are obsolete and inadaptable to modern teaching concepts.

Teachers should manage to perform the direction of learning methods and make the students form a good learning habit. In the process of remedying the knowledge deficit and instability of higher vocational college students, teachers should regard English learning and problem solving as carrier to make students be acquainted with the characteristics of thinking in English, try as far as possible to make them master more basic learning methods and skills and develop the ability to use those methods or skills neatly and freely.

Developing a good volition and high moral character is an effective approach to deal with $L D$. In teaching, teachers should purposefully and constantly educate students with the help of typical models and develop the strong learning volition of students and the perseverance of overcoming learning difficulties. In the meantime, it is vital to develop self-control of students in learning. In the classroom, teachers can remind their students, make their students be imposed under their own attention and have their students control their own attention by means of teachers' eyesight, expressions, gestures, pause and sound changes.

\section{2) Constructing Favorable External Learning}

\section{Environments}

Changing educational concepts and enhancing the construction of school culture and environment should be paid close attention to. Firstly, the traditional undergraduate education modes should not be stiffly applied to the higher vocational education and the training modes of the higher vocational education should adapt to requirements of the society. Secondly, it is our responsibility to improve colleges and their neighboring environments and enhance the construction of campus cultures. Thirdly, a favorable class discipline and a united classmate relation make for effective learning. A well-behaved class can generate positive effect on individual perception, emotion and volition through the group psychological feature and make an individual have a sense of belonging and identity.

It is urgent to fully exert the leading role of English teachers, promote their professional level, and stabilize their occupational status. Exerting the leading role of English teachers is one of the important means to solve English learning difficulties of higher vocational college students. In teaching it is necessary to consolidate influences of English teachers towards students because a harmonious relation between teachers and students and the teaching effect shows a positive correlation.

Teachers should teach students how to learn English well and manage to improve the classroom teaching efficiency. Firstly, students should be guided to decide their own study plans of various stages based on their learning situation. Secondly, it is necessary to develop students' habit of previewing before a class and reviewing after a class. Thirdly, in teaching teachers try to control, create and guide the internal and external learning conditions of students to make them master learning discipline and methods.

It is significant to ask parents for help and emphasize the importance of teaching reflection. It is quite important to organize students more to practice in companies and be acquainted with English practical value to their future work. On the other hand, parents should fully and deeply know the learning situation of their children and together with teachers explore solutions to deal with learning problems of their children.

Abundant extracurricular work and sufficient teaching periods must be met.

Teachers ought to manage to make the teaching administrations realize the importance of increasing English periods; on the other hand, they organize more extracurricular work to educate the self-taught ability of students.

\section{CONCLUSIONS}

It is important for us to enhance the stability, practicability and systematicness of the teaching material construction and development. It is urgent for us to enhance the compilation, selection, application and adaptation of teaching materials especially to consider learning needs of students. In the meantime, it is suggested that teaching administrations should guarantee the stability, systematicness and practicability of teaching materials as well.

\section{Reference}

[1] Adams, M. C. \& Bee, C. W. 1991. Teaching strategies in introductory sociology for college students with learning disabilities. Teaching Sociology, 19 (1), pp.42-47. 
[2] Chen, T. Y. 1997a. Indentifying language learning factors among Junior college students through diary studies. Paper from proceedings of the Fourteenth Conference on English Teaching in Taiwan Province, pp. 81-89, Taipei: The Crane.

[3] Chen, T. Y. 1997b. Foreign language learning frustration: Insight from diary studies. Paper from proceedings of the Sixth International Symposium on English Teaching, pp. 59-79, Taipei: The Crane.

[4] Chen, T. Y. 2001. Testing Chinese learners of English for language learning difficulties by the linguistic coding deficit differences hypothesis. RELC Journal, 32, p. 34.

[5] Fan, Y. \& Rui, Y. 1998. Foreign Language Teaching towards the $21^{\text {st }}$ Century: Hope and Solution (In Chinese). Chongqing: Chongqing Press.

[6] Ganschow, L. \& Sparks, R. L. 1995. Effects of direct instruction in Spanish phonology on the native language skill and foreign language aptitude of at-risk foreign language learners. Journal of Learning Disabilities, 28, pp. 107-120.

[7] Ganschow, L., Sparks, R. L. \& Javorsky, J. 1998. Foreign language learning difficulties: An historical perspective. Journal of Learning Disabilities, 31, pp. 248-258.

[8] Hirano, E. 2009. Learning difficulty and learner identity: A symbiotic relationship. ELT Journal, 63.

[9] Huang, G. 2008. A survey on English learning difficulties of higher vocational college students (In Chinese). Foreign Language Teaching and Research, 47.

[10] Johnson, D. W. 1979. Educational Psychology. Englewood Cliffs, NJ: Prentice Hall.

[11] Kaler, S. R. \& Kopp, C. 1990. Compliance and comprehension in very young toddlers. Child Development, 61.
[12] Kavale, K. A. \& Mostert, M. P. 2004. Social skills interventions for individuals with learning disabilities. Learning Disability Quarterly, 27 (1).

[13] Palladino, P. 2003. Foreign language learning disabilities. Psicologia Clinica Dello Sviluppo, 7, pp. 161-184.

[14] Qin, H. \& Yin, P. 2009. An exploration on students with English learning difficulties of higher vocational colleges and countermeasures (In Chinese). The Science Education Article Collects, 10.

[15] Simmons, D. C., Kameenui, E. J. \& Chard, D. J. 1998. General education teachers' assumptions about learning and

[16] students with learning disabilities: Design-of-instruction analysis. Learning Disability Quarterly, 21 (1).

[17] Sparks, R. L. 2006. Is there a "disability" for learning a foreign language? Journal of Learning Disabilities, 39, p. 544.

[18] Yao, P. 2002. High school students' deficiency in acquiring spoken English causes and countermeasures (In Chinese). Journal of Subject Education, 4.

[19] Yuan, R. 2006. An analysis on students with English learning difficulties of higher vocational colleges and countermeasures (In Chinese). China Adult Education, 5.

[20] Zheng, H. \& Lou, R. 2004. Psychological thinking to the education of students with English learning difficulties (In Chinese). China Higher Education Research,7. 